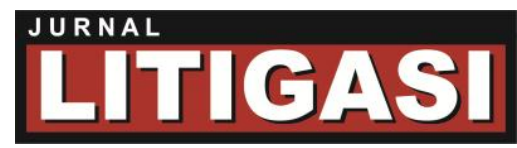

Available online at: http://ejournal.unpas.ac.id/index.php/litigasi

Litigasi, Vol. 16(2), 2015, 2906-2938

DOI: http://dx.doi.org/10.23969/litigasi.v16i2.38

\title{
KONSEP SISTEM HUKUM INVESTASI DALAM MEN]AMIN ADANYA KEPASTIAN HUKUM
}

\section{Jaja Ahmad Jayus}

Dosen Fakultas Hukum dan Magister Ilmu Hukum Pascasarjana Universitas Pasundan Bandung, Jl. Sumatera No. 41, Telp: 022-4210243 Bandung 40117, Email: jayus_ahmad@yahoo.com.

\begin{abstract}
ABSTRAK
Problem investasi di Indonesia salah satunya adalah persoalan kepastian hukum. Problem itu muncul baik karena terjadinya disharmonisasi perundang-undangan yang terkait maupun persoalan sinkronisasi. Padahal persoalan kepastian hukum merupakan hal yang diharapkan oleh setiap investor, hal tersebut karena investasi berkaitan dengan keuntungan yang diharapkan dimasa datang. Oleh karenanya perlu adanya penataan dari sisi peraturan perundang-undangan, maupun pelayanan. Penataan pelayanan perlu juga dibarengi dengan penataan sistem hukumnya. Oleh karenanya konsep sistem hukum investasi harus mencakup penataan hukum investasi dan undang-undang yang berkaitan, seperti persoalan hukum perburuhan, hukum perizinan yang mendorong adanya kepastian dan perlindungan bagi kelangsungan investasi.
\end{abstract}

Kata Kunci: Hukum Investasi; Kepastian Hukum; Hukum Perizinan

\begin{abstract}
The problems investiment in Indonesia one of them is the issue of legal certainty. The problem arises both because of the disharmony of law and issues related to synchronization. Whereas the issue of legal certainty is expected by each investor, it is because the investment related to the expected future profits. Hence the need for the arrangement of the law, as well as services. Structuring services should also be coupled with the arrangement of its legal system. Therefore, the concept of the legal system of investment should cover the legal structuring of investment and related legislation, such as the problem of labor laws, licensing laws that encourage certainty and protection for the survival of an investment.
\end{abstract}

Keyword: Investment Law; Legal Certainty; Licensing Law System

Copyright (C) 2015, LITIGASI, p-ISSN: 0853-7100; e-ISSN: 2442-2274 
Available online at: http://ejournal.unpas.ac.id/index.php/litigasi

Litigasi, Vol. 16(2), 2015, 2906-2938

DOI: http://dx.doi.org/10.23969/litigasi.v16i2.38

\section{PENDAHULUAN}

Perhatian penulis terhadap kondisi investasi di Indonesia dimulai pada tahun 1999 saat penulis melakukan kajian tesis dengan mengambil variabel penelitian Hukum Investasi dan Perizinan. Perhatian tersebut penulis teruskan ketika menyusun disertasi pada tahun 2004 sampai dengan tahun 2007. Dalam kurun waktu tersebut penyederhanaan dalam rangka memangkas hambatan investasi menjadi perhatian pemerintah dan dunia usaha. Perhatian tersebut juga menjadi masih jadi pembicaraan sampai dengan pemerintahan sekarang.

Setiap kegiatan ekonomi perlu dukungan hukum, karena tanpa dukungan hukum yang memadai dapat memunculkan ketiadan kepastian hukum, tentunya akan berdampak bagi kegiatan ekonomi itu sendiri. Kepastian hukum dapat memberikan rasa percaya bagi setiap pelaku ekonomi, karena pelaku ekonomi dapat memperediksi keuntungan yang diharapkan. Apabila keuntungan dapat diprediksi dengan jaminan kepastian hukum, maka bagi pelaku bisnis akan mudah untuk mengambil keputusan investasinya. Dukungan hukum bagi kegiatan ekonomi dapat diwujudkan dari proses produksi sampai proses distribusi, bahkan sampai pemberian perlindungan bagi konsumen.

Dalam kegiatan ekonomi, khususnya investasi masih terdapat aturan hukum yang seringkali dikeluhkan oleh para investor, antara lain masalah keamanan investasi, masalah prosedur perizinan, masalah penegakan hukum, masalah tenaga kerja/buruh yang sampai sekarang terus bergelut dengan persoalan upah dan tenaga kerja/buruh kontrak (outsourcing), serta berbagai persoalan lainnya.

Copyright @ C 2015, LITIGASI, p-ISSN: 0853-7100; e-ISSN: 2442-2274 
Akibatnya investasi di Indonesia dikategorikan dalam keadaan tidak nyaman. Padahal sesuai dengan sifat dari kegiatan investasi yang penuh risiko, maka kegiatan investasi harus didukung oleh suatu aturan yang mampu menciptakan kepastian (predictability), keadilan (fairness), efisiensi (efficiency). Terciptanya kepastian hukum, keadilan, efisiensi merupakan prinsip-prinsip hukum dalam suatu negara modern, selain prinsip-prinsip hukum menciptakan adanya kewajaran, ketenangan hidup (Prajudi Atmosudirdjo, $1998: 26$ ).

Selain persoalan intern tersebut, Indonesia dihadapkan pada suatu perubahan dalam iklim investasi, yaitu mulai dari kehadiran GATT-WTO, MEA, dan yang baru-baru ini masyarakat kawasan Pasific terbatas. Adanya kelembagaan tersebut beserta aturan didalamnya membawa implikasi untuk adanya penyesuaian berbagai aturan hukum di Indonesia, antara lain perlakuan yang sama antara investor asing dan domestik, ini berarti kedua aturan yang memayungi kegiatan investasi harus dirubah. Berbagai aturan hukum yang mungkin kurang harmonis, harus dilakukan harmonisasi. Konsep harmonis di sini maksudnya adalah keseimbangan berbagai kepentingan, yaitu antara lain keseimbangan kepentingan antara masyarakat dengan penguasa, sebagaimana cerminan dalam kandungan yang terdapat dalam Alinea kedua dan keempat Pembukaan UUD 1945.

Harmonisasi yang dilakukan di bidang penanaman modal seperti ketentuan yang tertuang dalam TRIM's, yaitu mengenai perlakuan yang sama sesama pelaku penanam modal. Ketentuan tersebut sekarang telah diakomodir dalam UndangUndang No. 25 Tahun 2007, sebagaimana tertuang dalam Pasal 3 ayat (1) dan 
Pasal 6 ayat (1) dan ayat (2), maka Indonesia tidak lagi terdapat perbedaan perlakuan terhadap semua penanam modal. Walaupun dalam praktek menimbulkan persoalan tentang kesiapan penanam modal dalam negeri untuk berkompetitif dengan penanam modal asing yang memiliki kemampuan modal yang lebih dari pada penanam modal dalam negeri.

Sejak penulis amati dari tahun 1999 selepas paket Otonomi Daerah sampai dengan sekarang, para investor masih saja mengeluhkan tentang persoalan investasi di Indonesia yaitu menyangkut aspek legal, labour, and local, sebagaimana disampaikan oleh Juwono Soedarsono (Harian Kompas Edisi Rabu 9 Juni, 2004 : 4), maupun beberapa pelaku usaha misalnya di Jawa Barat. Masalah yang sama juga muncul ketika dilakukan infrastruktur summit di Jakarta pada bulan Desember tahun 2004.

Namun keluhan tentang aspek hukum oleh pelaku usaha, ternyata dengan adanya Peraturan Pemerintah No. 78 Tahun 2015, dipandang berbeda oleh para tenaga kerja atau buruh melalui serikat pekerjanya. Keluhan tersebut antara lain, bahwa dengan PP tersebut akan memiskinkan buruh dan kenailkan upah di atas $10 \%$ sulit terwujud, sebaliknya pengusaha mempersoalkannya misalnya dari sisi balancing setiap daerah, karena setiap daerah memiliki karakteristik yang berbeda (Harian Tempo, Kamis 29 Oktober 2015 : 10). 
Dari persoalan tersebut dikemukakan identifikasi masalah sebagai berikut:

1. Bagaimana ketentuan aturan hukum dalam tata perundang-undangan dan praktik hukum di Indonesia yang dapat menjamin pemberian kepastian hukum bagi kegiatan investasi?

2. Bagaimana konsep sistem hukum investasi yang dapat menjamin adanya kepastian hukum bagi pelaku investasi dan masyarakat yang bekerja disektor kegiatan investasi?

\section{METODE PENELITIAN}

Norma menjadi pokok kajian dalam penulisan ini, dengan demikian penelitian ini bersifat deskriftif analitis dengan pendekatan yang yuridis normatif dan juga dilakukan pendekatan interdisipliner dan multidisipliner. Pendekatan yuridis normatif digunakan dengan menggunakan interpretasi (gramatikal dan otentik). Ilmu Hukum sebagai ilmu normatif memiliki cara kerja yang khas sebagai sui generis. Sui generis maksudnya adalah ilmu hukum sebagai ilmu jenis tersendiri. Sebagai ilmu, ilmu hukum memiliki cara kerja yang kas dan sistem ilmiah yang berbeda karena obyek perhatian yang berbeda. Kemudian norma dianalisis berdasarkan norma kualitatif. Dengan kata lain, analisis terhadap data yang ada dianalisis berdasarkan kaidah-kaidah interpretasi dan konstruksi hukum yang berlaku. Analisis itu meliputi (i) bahwa perundang-undangan yang satu dengan yang lain tidak bertentangan (ii) ketentuan mengenai hierarchi perundang- 
Available online at: http://ejournal.unpas.ac.id/index.php/litigasi

Litigasi, Vol. 16(2), 2015, 2906-2938

DOI: http://dx.doi.org/10.23969/litigasi.v16i2.38

undangan (iii) kepastian hukum, artinya apakah aturan dilaksanakan secara konsisten.

\section{HASIL PENELITIAN DAN ANALISIS}

A. Kajian Terhadap Produk Hukum dan Praktik Penegakkan Hukum Dalam Melihat Adanya Jaminan Kepastian Hukum Bagi Kegiatan Investasi

Dengan adanya aturan hukum, maka seharusnya memberikan patokan bagaimana seharusnya berprilaku. Kenyataan hukum merupakan wujud nyata dari norma yang seharusnya tersebut diimplementasikan. Kenyataannya dapat terjadi aturan sebagai patokan, berbeda dengan yang seharusnya. Pada sisi lain harus dibedakan pula antara istilah kenyataan hukum dengan hukum yang hidup. Istilah kenyataan hukum dalam bahasa Belanda adalah "rechtswerkelikheid". Logemann dengan mengemukakan bahwa hukum yang pasti (stellig recht) selalu merupakan suatu peraturan tertentu (regel), sedang kenyataan hukum (rechwerkelikheid) selalu berupa suatu keputusan para penguasa berdasar atas peraturan hukum itu. Keputusan itu tidak selalu sama, berlainan keputusan disebabkan oleh cara menafsirkan peraturan hukum yang bersangkutan oleh banyak hal. Istilah hukum yang hidup merujuk kepada hukum yang benar-benar diturut dalam masyarakat, disamping hukum berupa peraturan resmi atau formil (Wirjono Prodjodikoro, 1981: 42-43).

Dalam penegakan hukum dapat dibedakan pengertian penerapan hukum, penegakan hukum dan pelayanan hukum. Bagir Manan memberikan perbedaan

Copyright @ 2015 , LITIGASI, p-ISSN: 0853-7100; e-ISSN: 2442-2274 
itu, Penerapan hukum atau "law applying" merupakan genus atau pengertian umum dari penegakan hukum (law enforcement), dan pelayanan hukum (legal service). Mewujudkan suatu norma secara konkret tidak selalu sama dengan hukum yang hidup (Bagir Manan, 2002: 3).

Dalam peristiwa konkret dapat dilihat terdapat norma yang dilaksanakan yang dilanggar kemudian diterapkan terhadap suatu kaidah yang ada dalam undang-undang. Sebagai contoh orang melakukan transaksi jual beli tanah, maka berlaku ketentuan dalam Pasal 19 Undang-Undang No. 5 Tahun 1960 jo. Pasal 26 Peraturan Pemerintah No. 23 Tahun 1997 tentang Pendaftaran Tanah, maka setiap yang bertransaksi atas tanah untuk keabsahan dan kepastian dilakukan di hadapan PPAT. Begitu pula dalam kegiatan investasi, untuk melakukan investasi harus didasarkan pada Undang-Undang Penanaman Modal No. 25 Tahun 2007.

Dapat juga dilihat dalam hal konkret terdapat proses yang tidak sesuai dengan norma yang ditetapkan, seperti mengurus perizinan supaya cepat, pakai uang pelicin, dan banyak perbuatan aparatur dan masyarakat yang menyimpang dari aturan berjalan pada aturan itu sendiri. Itulah hukum nyata atau konkret. Dalam pandangan paham hukum legal realism atau yang terbaru paham hukum kritis itulah hukum. Dari kenyataan itu mengemukakan pengertian mewujudkan hukum pada suatu peristiwa konkret dengan istilah The Law In Action, dan hukum dalam arti konkret diistilahkan dengan istilah the living law. Kedua istilah tersebut secara sosiologis merupakan pengertian umum dan dapat disebut sebagai The 
Living Law dalam arti sebagai hukum yang nampak, dilihat, atau dialami sebagai hukum oleh masyarakat (Bagir Manan, 2002: 4).

BKPM telah mengeluarkan suatu kebijakan bahwa Izin prinsip dapat keluar dalam waktu hitungan jam dalam hari yang sama ketika para investor mengajukan permohonan. Kebijakan baru ini harus menjadi filosofi dasar perizinan di daerah, oleh karenanya perizinan di daerah harus menyesuaikan dengan semakin tersebut.

Penegakan hukum (law enforcement) merupakan salah satu aspek penerapan hukum, merupakan fungsi atau tindakan mempertahankan hukum agar hukum ditaati, berjalan, atau dijalankan sebagaimana mestinya. Penegakan hukum merupakan reaksi dari peristiwa yang sesuai atau bertentangan dengan hukum (Bagir Manan, 2002: 4).

Dalam bidang penanaman modal, penegakan hukum ini menjadi topik yang menarik. Hal ini berkaitan apakah dalam kegiatan penanaman modal terdapat nilai kepastian dan perlindungan hukum bagi investor. Sebabnya ini penting, karena investor seringkali menginginkan terdapatnya jaminan atas modal dan prediksi keuntungan atas modal yang ditanam.

Secara yuridis normatif, jaminan atas kepastian dan perlindungan hukum telah diberikan oleh Undang-Undang No. 25 Tahun 2007 sebagai pengganti atas Undang-Undang No. 1 Tahun 1967 jo Undang-Undang No. 11 Tahun 1970 dan Undang-Undang No. 6 Tahun 1968 jo Undang-Undang No. 12 Tahun 1970.

Copyright @ 2015, LITIGASI, p-ISSN: 0853-7100; e-ISSN: 2442-2274 
Jaminan atas investasi yang diberikan oleh undang-undang di bidang penanaman modal, antara lain melalui asas non-nasionalisasi. Asas Non Nasionalisasi telah tertuang sebagaimana dalam Pasal 21 UU No. 1 Tahun 1967 mengatakan "Pemerintah tidak akan melakukan tindakan nasionalisasi/pencabutan hak milik secara menyeluruh atas perusahaan-perusahaan modal asing atau tindakan-tindakan yang mengurangi hak yang menguasai dan atau mengurus perusahaan yang bersangkutan, kecuali jika dengan undang-undang dinyatakan kepentingan negara menghendaki tindakan demikian". Ketentuan tersebut juga tertuang dalam Pasal 7 UU No. 25 Tahun 2007. Dalam Pasal tersebut dinyatakan bahwa pemerintah tidak akan melakukan tindakan nasionalisasi, apabila pemerintah melakukan tindakan nasionalisasi maka akan diberikan kompensasi dengan harga pasar, dan apabila tidak ada kesepakatan akan diselesaikan melalui arbitrase.

Kecuali tindakan nasionalisasi perusahan milik Belanda pada tahun 1958, Indonesia belum pernah melakukan tindakan yang serupa terhadap perusahaan asing yang bergerak dalam penanaman modal di Indonesia. Kalaupun terjadi tindakan nasionalisasi, maka undang-undang memberikan jaminan, bahwa ada kewajiban dari Pemerintah untuk memberikan kompensasi. Kompensasi yang diberikan berdasarkan prinsip hukum internasional. Sebagaimana diketahui prinsip hukum internasional untuk memberikan kompensasi ganti rugi didasarkan pada asas promt, efektive, dan adequate.

Copyright @ $\odot$ 2015, LITIGASI, p-ISSN: 0853-7100; e-ISSN: 2442-2274 
Hukum merupakan kontributor utama bagi keabsahan kegiatan pembangunan, yaitu untuk memberikan perlindungan, kepastian hukum, dan keadilan. Argumentasi ini didasarkan pada suatu pemahaman bahwa kegiatan investasi lebih menarik menciptakan infrastruktur investasi yang memadai, termasuk infrastruktur administrasi dan hukum. Daripada pemberian insentifinsentif pajak untuk investasi jangka panjang. Mochtar Kusumaatmadja, mengemukakan bahwa pemberian insentif dalam investasi jangka panjang kurang menarik, yang lebih penting adalah menyiapkan perangkat hukum yang memadai (1995: 2-3).

Pernyataan Mochtar Kusumaatmadja tersebut, jelas bahwa kontek hukum dan pembangunan menempatkan peraturan perundang-undangan sebagai sumber hukum utama. Shidarta mengemukakan sumber hukum utama yang dijadikan acuan adalah peraturan perundang-undangan. Norma-normanya memuat kebijakan publik yang sebagian telah diimplementasikan. Kebijakan ini dievaluasi kemudian dicocokan dengan kebutuhan yang pendekatan penelitiannya bersifat empiris. Hasil penelitian ini diberi perspektif pragmatis, yaitu kesesuaian dengan kepentingan pembangunan nasional, pada akhirnya teori hukum pembangunan tetap menggunakan pola penalaran Positivisme Hukum (Shidarta: 421).

Konteks hukum harus memberikan kontributor utama bagi keabsahan kegiatan pembangunan, dapat memberikan perlindungan dan kepastian hukum, sebaliknya apabila hukum tidak mendukung, atau hukum disusun dan atau dirumuskan dengan tidak menggunakan prinsip hukum yang baik, sebagai misal

Copyright (C) 2015, LITIGASI, p-ISSN: 0853-7100; e-ISSN: 2442-2274 
kurang taat asas dalam tata cara pembuatan aturan, tidak taat asas dalam penerapan asas undang-undang - ini akan membawa implikasi tiadanya perlindungan dan kepastian hukum. Misalnya dengan menggunakan interpretasi atas kaidah yang tercermin dalam Peraturan Daerah Kota Bandung No. 26 Tahun 2002, terdapat implikasi dua pasal yang bertabrakan. Pasal 19 Perda Kota Bandung No. 26 Tahun 2002 dikatakan bahwa "setiap pemegang izin PMA/PMDN yang melanggar Peraturan Daerah ini dapat dikenakan sanksi administrasi sebagai berikut: a. Peringatan tertulis sebanyak 3 (tiga) kali; b. Pembatalan; c. Pencabutan. Pada aspek lain terhadap pelanggaran Perda ini dapat dikenakan sanksi pidana, sebagaimana diatur dalam Pasal 23 Perda No. 26 tahun 2002. Ketentuan sanksi ini sesuai dengan yang tercantum dalam Undang-undang tentang Pemerintahan Daerah No. 32 Tahun 2004 tentang Pemerintahan Daerah.

Memperhatikan kedua pasal tersebut, dengan menggunakan interpretasi sistemik - keharmonisan antara pasal yang satu dengan yang lainnya, menunjukan pemaknaan yang tidak jelas tentang sanksi apa yang akan dikenakan, karena kedua sanksi itu hanya menekankan apabila ada pelanggaran terhadap Perda tersebut dapat dikenakan sanksi administrasi dan atau sanksi pidana. Telaahan atas kedua norma tersebut adalah penting dalam penelitian ilmu hukum, karena penelitian hukum salah satunya adalah apakah suatu pengaturan hukum atas suatu perbuatan hukum dilandasi oleh prinsip hukum, teori hukum, atau filsafat hukum. (Johnny Ibrahim: 48).

Copyright @ 2015 , LITIGASI, p-ISSN: 0853-7100; e-ISSN: 2442-2274 
Seharusnya, diberikan rambu dan kualifikasi mana yang merupakan perbuatan yang dapat dikenakan sanksi administratif, mana yang dapat dikenakan sanksi pidana. Dengan demikian telah terjadi disharmoni internal aturan itu sendiri.

Dalam kegiatan penanaman modal hal penting lainnya adalah berkaitan dengan ketaatan dalam masalah kontrak. Sebagai misal dalam kasus Hotel Kartika Plaza versus PT. Amco Asia Corporation, bermula dalam implementasi kontrak yang telah dibuat. Bahwa para pihak telah sepakat apabila terjadi sengketa akan di bawa ke forum arbitrase ICC di Paris. Kenyataannya sengketa diselesaikan oleh forum ICSID, dan hasil keputusan dari Arbitrase ICSID ternyata tidak dilaksanakan secara serta-merta. Tidak dilaksanakannya hasil keputusan forum penyelesaian sengketa, merupakan indikator adanya pelanggaran terhadap perilndungan hukum bagi setiap pihak yang memerlukan perlindungan hukum. Pola penyelesaian sengketa melalui forum mana yang dipilih masih saja terjadi dengan membenturkan obyek yang menjadi sengketa seperti misalnya dalam kasus PT Berkah. Implikasi dari berbagai kasus tersebut, menimbulkan pertanyaan tentang efektivitas pola penyelesaian untuk memperoleh kepastian hukum dalam mengakhiri perbedaan permasalahan hukum dalam dunia usaha.

\section{B. Konsep Hukum Investasi Dalam Memberikan Jaminan Kepastian Hukum Bagi}

\section{Pelaku Investasi dan Masyarakat Yang Bekerja Pada Sektor Investasi}

Salah satu tujuan dari harmonisasi hukum adalah berupaya mencari keseragaman atau titik temu dari prinsip-prinsip yang bersifat fundamental dari berbagai sistem hukum yang ada (Huala Adolf, 2005: 31 dan 80). Pengertian

Copyright @ C 2015, LITIGASI, p-ISSN: 0853-7100; e-ISSN: 2442-2274 
harmonisasi dapat diartikan dari sisi metodologis, berarti melakukan kegiatan untuk mencari keseragaman dalam aturan formil. Secara bahasa harmonis berarti selaras, serasi. Harmonisasi berarti pengharmonisan, hal membentuk harmonis (Badudu-Zein, 1994: 499). Harmonisasi juga adalah keseimbangan berbagai kepentingan, yaitu antara lain keseimbangan kepentingan antara masyarakat dengan penguasa, sebagaimana cerminan dalam kandungan yang terdapat dalam Alinea kedua dan keempat Pembukaan UUD 1945.

Berbicara mengenai harmonisasi hukum, harus memperhatikan keadaan politik hukum dewasa ini. Pengaturanya dapat dikategorikan pengaturan yang mengatur organisasi pemerintahan, administrasi sipil, aktivitas dunia usaha, dan kehidupan sosial (Harian Kompas, Jumat 24 Maret 2006: 6).

Ketiga rumpun terakhir hampir terdapat aspek pungutan dalam substansi peraturan terutama dalam Peraturan Daerah. Khusus mengenai aktivitas sipil dan usaha, perda bermasalah mengoreksi atas prilaku kualitas pengurusan oleh birokrasi dan besarnya pungutan. Pelayanan publik yang merupakan kewajiban pemerintah justru dijadikan sarana untuk memperoleh sumber pendapatan asli daerah, akibatnya seolah terdapat proyek bisnis. Robert Endi Jaweng mengajukan solusi mengatasi perda bermasalah, yaitu adanya prinsip saling terkait antar fungsi, baik di pusat maupun di daerah. Ketiadaan dalam proses ini mengakibatkan kebijakan cacat kualitas. Kedua, untuk mendapatkan kualitas perda dan mendapat dukungan dalam pelaksanaan, maka keterlibatan dunia usaha dalam berpartisipasi merumuskan perda adalah mutlak. Atas fakta tersebut, sekarang ini banyak 
Pemerintah Daerah mengeluarkan kebijakan pemangkasan birokrasi dengan dibentuknya Pelayanan Terpadu atau Satu Atap. Namun demikian, mengapa pelaku usaha masih mengeluhkan lambanya proses pemberian izin. Hemat penulis, ini disebabkan penataan baru sebatas birokrasinya, belum menyentuh substansi hukum itu sendiri.

Selama ini keterlibatan dunia usaha kalaupun tidak ada adalah sangat minim. Oleh karenanya ke depan harus dipenuhi tiga syarat deliberasi, yaitu prosedur keterlibatan inklusif, kemauan aktif masyarakat untuk terlibat, dan mekanisme komplain bila perda itu tidak mengakomodasi masyarakat (Harian Kompas, Jumat 24 Maret 2006: 6). Dalam menyusun suatu produk hukum termasuk Peraturan Daerah maka proses melahirkan substansi harus melibatkan partisipasi masyarakat, hal ini dimaksudkan agar norma yang dilahirkan mencerminkan hukum yang nyata, sebaliknya kalau tidak melibatkan partisipasi publik kemungkinan yang terjadi normanya tidak mencerminkan hukum yang nyata atau kurang memenuhi sifat pembaharuan dan pengayoman. Kalau itu terjadi, maka tidak sesuai dengan konsep hukum dan pembangunan sebagaimana yang dikemukakan oleh Mochtar Kusumaatmadja. Mochtar Kusumaatmadja sebagaimana telah dikemukakan dalam bagian sebelumnya, dalam kontek hukum dan pembangunan, hukum tidak saja menciptakan ketertiban, kepastian, tetapi harus dapat berperan di depan melakukan pembaharuan terhadap masyarakat. Dalam konteks ini yang diperbaharui adalah, baik hukumnya maupun 
masyarakatnya diarahkan kepada sesuatu yang diinginkan. Sesuatu yang diinginkan seharusnya tidak destruktif, tetapi harus konstruktif.

Konteks hukum dalam keadaan demikian, sasaran pembaharuan tidak saja pada unsur masyarakat dan hukumnya, tetapi meliputi birokrasinya. Dalam kaitan ini Romli Atmasasmita menekankan bahwa fungsi hukum sebagai sarana pembaharuan mampu menciptakan harmonisasi antara elemen birokrasi dan elemen masyarakat ke dalam satu wadah yang disebut bureaucratic and social engineering. Jadi disini hukum berfungsi sebagai a tool of social and bureaucratic engineering (Romli Atmasasmita, 2006: 14-15).

Pada Tahun 2005, penulis melakukan kajian pada 40 peraturan daerah. Dari peraturan daerah tersebut dibatalkan oleh Mendagri atas rekomendasi Menteri Keuangan. Pembatalannya dengan kategori sebagai berikut (Bagian Hukum Departemen Perdagangan RI):

1. Bertentangan dengan pengaturan besarnya pajak atau retribusi yang harus dipungut;

2. Duplikasi dengan pengenaan pajak yang merupakan obyek pajak pusat;

3. Pengenaan pajak tersebut mengakibatkan ekonomi biaya tinggi;

4. Kelembagaan yang menetapakan besarnya pajak dan retribusi, seharusnya dalam bentuk Peraturan Daerah, tetapi ditepkan oleh Bupati;

5. Bertentangan dengan perundang-undangan yang lebih tinggi.

Data diolah dari Tim Pengkajian Perda tentang Pajak dan Retribusi Daerah ;

Bahan Rapat Pleno Tanggal 21 Desember 2005. Kulaifikasi Perda mengatur

Copyright @ C 2015, LITIGASI, p-ISSN: 0853-7100; e-ISSN: 2442-2274 
tentang 1) Energi dan Sumber Daya Mineral; 2) Komunikasi dan Informasi; 3)

Perhubungan; 4) Kesehatan; 5) Pertanian dan Peternakan; 6) Koperasi dan UKM.

Sebagai contoh misalnya Peraturan Daerah yang mengenakan retribusi perizinan di bidang industri dan perdagangan yang dibatasi waktunya, sedangkan dalam ketentuan perundang-undangan di atasnya, seperti diatur dalam Peraturan Pemerintah No. 13 Tahun 1995 tentang Izin Usaha Industri - izin usaha industri berlaku selama perusahaan tersebut beroperasi. Untuk Kota Bandung misalnya terdapat Peraturan daerah yang dibatalkan karena alasan bertentangan dengan Peraturan Pemerintah No. 13 Tahun 1995 tentang Izin Usaha Industri. Pada peraturan pemerintah tersebut, izin usaha industri diberikan selama perusahaan tersebut beroperasi. Namun dalam Perda Kota Bandung No. 26 Tahun 2001 tentang Pelayanan di Bidang Pertanian, ditetapkan izin usaha berlaku selama 1 (satu) tahun.

Selain menyempurnakan UU Investasi, Pemerintah juga telah mengeluarkan kebijakan yang pada dasarnya memberikan insentif kepada para investor yang akan menanamkan modalnya ke Indonesia. Hanya saja, regulasi soal pemberian insentif ini harus dikaji secara matang, sehingga tidak menjadi bumerang bagi pemerintah maupun para investor itu sendiri. Yang jelas, regulasi tentang pemberian insentif kepada para investor pada dasarnya akan menciptakan iklim investasi yang kondusif. Menyadari hal tersebut, Indonesia telah memiliki regulasi untuk merangsang para investor untuk menanamkan modalnya di Indonesia,

Copyright $\odot$ 2015, LITIGASI, p-ISSN: 0853-7100; e-ISSN: 2442-2274 
melalui UU No. 25 Tahun 2007, PP No. 45 Tahun 2008 tentang Pedoman Pemberian Insentif dan Pemberian Kemudahan Penanaman Modal di Daerah, dan Peraturan Menteri Dalam Negeri No. 64 Tahun 2012 tentang Pedoman Pelaksanaan Pemberian Insentif dan Pemberian Kemudahan Penanaman Modal di Daerah.

Dalam rangka penanaman modal, arah pembangunan diarahkan untuk meningkatkan arus penanaman modal baik dalam negeri maupun asing. Untuk itu, pemerintah telah mencanangkan untuk menciptakan sistem pelayanan investasi yang efisien dan efektif dan terciptanya kepastian iklim investasi yang kondusif (Bahan Rapat Pleno Tanggal 21 Desember 2005butir 5.1.1.: IV-59).

Dengan demikian, rumusan bagaimana menciptakan pelayanan investasi yang efisien, efektif, dan terciptanya kepastian memerlukan perangkat aturan yang dapat menjawab kebijakan tersebut. Dan dalam kaitan ini orientasi dari pemerintah harus bergeser dari sifat Command and Control kearah tuntutan dan kebutuhan publik. Peran pemerintah di sini lebih sebagai stimulator, fasilitator, koordinator dan enterpreneur dalam pembangunan (Mardiasmo, 2002: 8).

Kewenangan memberikan izin investasi bagi daerah dalam rangka Otonomi Daerah sangat penting, karena pergerakan ekonomi pada pokoknya adalah terletak pada arus sumber dana (Syahriel Nochtar, 2001: 44). Salah satu sumber dana adalah adanya aliran arus modal atau investasi langsung (direct investment) ke daerah. Melihat kenyataan dalam tabel di atas, iklim investasi di Jawa Barat 
dalam keadaan krisis masih terjadi, walaupun tidak menunjukan angka yang mengembirakan sebagaimana dilihat dalam tabel tersebut di atas.

Dalam rangka meningkatkan investasi, antara lain diupayakan untuk mempermudah pemberian pelayanan perizinan investasi dengan memperbanyak pusat pelayanan pemberian persetujuan/perizinan investasi. Selain dari pada itu, sejalan dengan semangat otonomi daerah, harus pula dibarengi dengan penataan birokrasi.

Oleh karenanya dengan melihat jenis izin yang ada baik di Kabupaten maupun Kota, dalam kerangka penanaman modal jenis izinnya dapat disederhanakan dengan mengacu kepada jenis sistem perizinan, yaitu pola integratif, berantai, atau sektoral. Sistem perizinan menyangkut aspek legalitas dari izin. Aspek legalitas dari izin ini meliputi keabsahan dari tujuan, keabsahan wewenang, prosedur, substansi, penegakan hukum. Dengan demikian dikaitkan dengan perlindungan hukum, izin akan memberikan perlindungan hukum apabila memiliki keabsahan legalitasnya.

Memperhatikan bentuk pola pelayanan perizinan, pelayanan dalam bidang penanaman modal dilakukan dengan pola satu atap, menunjukan bahwa kewenangan berada pada departemen masing-masing. Ini dapat mengakibatkan, pelayanan hanya menerima proses, tetapi tidak dapat menyelesaikan. Dampaknya dapat saja si pemohon melakukan kontak dengan instansi dimana kewenangan tersebut berada.

Copyright (C) 2015, LITIGASI, p-ISSN: 0853-7100; e-ISSN: 2442-2274 
Dalam implementasinya, untuk memulai kegiatan investasi sampai usahanya berjalan, maka masih terlihat berbagai jenis izin untuk diselesaikan oleh investor, selain izin prinsip, maka izin sektoral harus diselesaikan. Terhadap jenis izin yang sifatnya sektoral supaya penataan birokrasinya sejalan damn implementatif dengan penyederhanaan, maka menurut hemat penulis perlu adanya kualifikasi izin yang memiliki tujuan yang sama. Terhadap tujuan yang sama dapat dikelompok sebagai satu jenis izin, sehingga jenisnya menjadi sederhana. Sebagai contoh kelompok izin yang berkaitan dengan lingkungan dan tata ruang, izin yang berkaitan dengan usaha langsung, izin yang berkaitan dengan pemberian fasilitas. Dengan kualifikasi tersebut, sistem perizinan dapat disederhanakan.

Penyederhanaan jenis izin harus dibarengi pula dengan kewenangan kelembagaan. Adanya kewenangan yang langsung akan mempermudah untuk memproses dan mengevaluasi izin tersebut. Hal tersebut sesuai dengan apa yang menjadi rasionalitas daripada izin, (Asep Warlan Jusup, 1999-2001) yaitu:

a. Suatu izin harus memenuhi syarat normatif, artinya dapat menentukan persyaratan, melakukan pengawasan, dan menerapkan sanksi secara efektif.

b. Memiliki nilai, ini berkaitan dengan perlindungan hukum;

c. Melaksanakan manajerial, yaitu menyangkut aspek birokrasi, dan fungsi pelayanan;

d. Izin berkaitan dengan kelayakan teknis. 
Urgensi dari penyederhanaan izin dalam rangka investasi telah menjadi perhatian oleh Pemerintah. Hal tersebut dapat terlihat dari Paket Kebijakan Ekonomi September 2015, terlihat terdapat 3 (tiga) variabel utama paket tersebut, yaitu deregulasi, debirokratisasi, dan kepastian hukum. Sebagai contoh dalam paket tersebut mengharmoniskan UU No. 13 Tahun 2003 tentang Ketenagakerjaan, UU No. 30 Tahun 2009 tentang Ketenagalistrikan, dan UU No. 28 Tahun 2002 tentang Bangunan Gedung. Intinya mengintegrasikan perizinan (IMB) yang berkaitan dengan bangunan dan keselamatan kerja.

Pranata hukum yang dapat menjamin kepastian hukum terletak bagaimana perumusan pranata hukum tersebut dalam produk perundang-undangan. Hal ini didasarkan, bahwa perundang-undangan dapat menjamin tingkat kepastian hukum, apabila dirumuskan sesuai dengan asas, teori, dan filsafat hukum yang dikandungnya. Suatu perundang-undangan untuk menjamin adanya kepastian hukum tidak saja harus memenuhi persyaratan formil, tetapi terdapat syaratsyarat substansial yang harus dipenuhi, yaitu antara lain: 1) perumusannya harus jelas (unambiguous); 2) Terdapat konsistensi dalam perumusannya; 3) penggunaan bahasa yang tepat, dan mudah dimengerti (Bagir manan: 254).

Hal ini didasarkan pada pemaknaan dari pranata sebagai suatu sistem aktivitas khas dari kelakuan berpola (wujud kedua dari kebudayaan) beserta komponen-komponennya, ialah sistem norma dan tata kelakuannya (wujud pertama kebudayaan) dan peralatannya (wujud ketiga kebudayaan) ditambah dengan manusia (personel) yang melaksanakan kelakuan berpola tersebut 
(Badudu-Zain, 1994: 1086). Dengan demikian suatu pranata berarti suatu tatanan - suatu sistem aturan. Hans Kelsen mengartikan tatanan sebagai suatu system aturan. Hukum adalah seperangkat peraturan yang mengandung semacam kesatuan yang dipahami melalui sebuah sistem.

Berbicara kepastian terdapat dua dimensi, yaitu kepastian dalam hukum dan kepastian oleh karena hukum (Soerjono Soekanto, 1983: 42). Ini sesuai dengan sifat hukum, yaitu hukum mengatur, juga menyelesaikan ketika terjadi sengketa hukum. Di sinilah letaknya antara hukum yang dicitakan dengan kenyataan hukum. Hukum yang seharusnya dan hukum dalam implementasinya.

Untuk meningkatkan daya saing maka harus ada pembenahan dalam pelayanan hukum. Pelayanan hukum merupakan fungsi pemerintahan. Terdapat beberapa hal yang harus diperhatikan dalam meningkatkan pelayanan umum, yaitu:

a. Pelaksanaan pelayanan hukum harus dilaksanakan sesuai dengan asasasas umum penyelenggaraan pemerintahan yang baik;

b. Pembaharuan tatanan birokrasi.

Untuk memaksimalkan fungsi pelayanan, maka harus dilakukan langkah (Bagir Manan, 2004: 251-252):

a. Penyederhanaan tata cara dan kewenangan pelayanan;

b. Melepaskan fungsi pelayanan sebagai instrument sumber keuangan;

c. Mengurangi unsur-unsur yang terlalu diarahkan pada fungsi pengawasan dan pengendalian, lebih diarahkan pada fasilitas daripada pengawasan;

Copyright (C) 2015, LITIGASI, p-ISSN: 0853-7100; e-ISSN: 2442-2274 
Available online at: http://ejournal.unpas.ac.id/index.php/litigasi

Litigasi, Vol. 16(2), 2015, 2906-2938

DOI: http://dx.doi.org/10.23969/litigasi.v16i2.38

d. Melepaskan keterkaitan birokrasi dari kekuatan-kekuatan politik masyarakat.;

e. Penyusunan kembali secara mendasar hubungan kewenangan untuk mencegah atau menghilangkan tumpang tindih, ketidakpastian dan lain sebagainya;

f. Perencanaan yang sistemik mengenai pembinaan sumber daya manusia, baik mutu, kesejahteraan, karismatis, dan sebagainya.

Untuk meningkatkan daya saing perlu kiranya menata pemerintahan seperti pola yang dikemukakan oleh David Osborne dan Ted Gaebler. Pola yang dikemukakan oleh David Osborn dan Ted Gaebler merupakan pola New Public Management yang pada pokoknya berfokus pada manajemen, penilaian kinerja, dan efisiensi bukan berorientasi pada kebijakan (Mardiasmo, 2002: 13).

Pemerintah sebaiknya memberikan wewenang kepada masyarakat daripada melayani, sebagai contoh dalam rangka mengembangkan usaha kecil, maka berilah wewenang kepada asosiasi pengusaha kecil untuk memecahkannya sendiri, pemerintah jadi fasilitator. Konsep yang dikemukakan oleh Osborn ini dikenal dengan konsep Reinventing Government. Konsep reinventing Government yang ditawarkan oleh David Osborn dan Ted Gaebler ini meliputi: 1) Pemerintahan Katalis; 2) Pemerintah Milik Masyarakat; 3) Pemerintah Yang Kompetitif; 4) Pemerintah yang digerakan oleh misi; 5) Pemerintah yang berorientasi hasil; 6) Pemerintah berorientasi pada pelanggan; 7) Pemerintah Wirausaha; 8) 
Pemerintah Antisipatif; 9) Pemerintah desentralisasi; 10) Pemerintah Berorientasi Pada mekanisme Pasar.

Untuk adanya reengineering birokrasi dalam memberikan jaminan adanya pelayanan publik maka perlu adanya penyederhanaan birokrasi. Dalam hal ini dalam upaya untuk menciptakan kepuasan, oleh karenanya perlu diciptakan sistem pelayanan dan mekanisme kerja yang dapat menciptakan peluang adanya praktik-praktik tidak terpuji, seperti pungutan.

Joko Widodo dalam Good Governance mengemukakan pendapat David Osborn dan Ted Gaebler, bahwa pemerintahan masa depan harus berorientasi pada mengendalikan atau mengatur semata. Kemudian mengemukakan mekanisme kerja dan pelayanan harus diusahakan sesederhana mungkin prosedurnya, waktu yang cepat, dan biaya yang murah (2004: 32 ).

Perizinan yang terlalu birokratis melanggar prinsip servis publik, yaitu bukannya memberikan nilai sejahtera kepada masyarakat tetapi membebani. Oleh karena itu harus dilakukan pendekatan paradigmatik untuk memecahkan kebuntuan birokrasi perizinan.

Dalam menggunakan pendekatan paradigmatik dari Thomas Khun, Talijiduhu Ndraha, menggambarkan tentang pasang surut dalam IImu Pemerintahan. Digambarkannya IImu Pemerintahan pada saat lahir di tangan van Poelje dianggap sebagai paradigma pertama, yaitu "ilmunya manusia", dan pada masa perkembangannya di Eropa dan Amerika menjadi normal science (Ilmunya pemerintah, digunakan untuk kesejahteraan masyarakat, ketika ia memasuki 
Indonesia pada tahun 1950-an, digunakan oleh pejabat pemerintah selama lebih kurang 4 dekade, IImu pemerintahan dijadikan sebagai alat untuk menjadikan manusia (yang diperintah) sebagai bawahan pemerintah (periode anomali), periode berikutnya periode krisis pada awal tahun 1990-an yang ditandai gerakan reformasi tahun 1998, ilmu perintahan ibarat sampah, sehingga perlu revolusi menuju paradigma II, yaitu IImu Pemerintahan Modern. Sebagai ilustrasi dapat digambar sebagai berikut (Talijiduhu Ndraha, $2000: 10-12$ ):

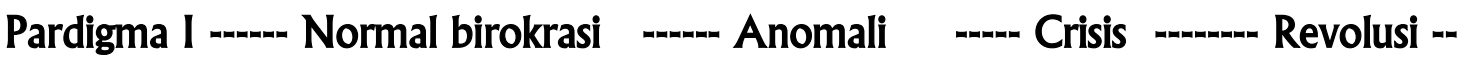 -- Paradigma II --m Koreksi ---- Paradigma III}

Paradigma I dapat digambarkan bahwa perizinan yang diterapkan di Indonesia menggunakan pola sentralistik dan hal itu berlangsung selama pemerintahan sentralistik yang telah melahirkan pertumbuhan ekonomi $7,8 \%$, tetapi kenyataannya itu dikeluhkan oleh para pelaku usaha, kemudian muncul pertentangan terhadap sentralistik, dan melahirkan otonomi daerah, terdapat krisis multidimensional revolusi di bidang perizinan, muncul konsep pelayanan satu atap, namun perizinannya masih sektoral. Pada paradigma baru (II), perizinan hendaknya tidak saja pelayanannya yang terpadu tetapi sistem perizinannya diarahkan kedalam pola yang mendukung pelayanan satu atap atau terpadu tersebut, yaitu dirumuskan dalam bentuk integratif atau berantai. Pada paradigma III, apabila ada hambatan dikoreksi terutama pada bagian struktur hukum dan budaya hukum sehingga menjadi ideal.

Copyright @ $\odot$ 2015, LITIGASI, p-ISSN: 0853-7100; e-ISSN: 2442-2274 
Dalam kerangka investasi, perizinan investasi merupakan sub sistem hukum investasi. Dalam sub sistem tersebut, terdapat sub-sub sistem perizinan, yaitu meliputi fungsi, kewenangan pemberi izin, ruang lingkup izin, prosedur, dan sanksi. Fungsi perizinan investasi hendaknya tidak dijadikan sebagai sarana pendapatan, tetapi sebagai pengendali, pengarah, perekayasa masyarakat (Sjahran Basah, 1996: 02). Dalam uraian tersebut Sjachran Basah mengemukakan bahwa izin merupakan perkenan menyelenggarakan peraturan dalam hal konkreto, berfungsi selaku ujung tombak instrumen hukum sebagai pengarah, perekayasa dan perancang masyarakat adil dan makmur itu dijelmakan.

Hal tersebut berangkat dari sub-sub sistem perizinan tersebut, bahwa izin mempunyai fungsi pengendalian, perekayasa ke arah masyarakat sejahtera dan cita dari hukum itu lahir, yaitu ketertiban dan keteraturan.

Prinsip hukum investasi dalam UU Penanaman Modal, antara lain misalnya menganut prinsip-prinsip atau yang berkaitan dengan perlindungan, antara lain menganut asas-asas kepastian hukum, perlakuan yang sama dan tidak membedakan asal Negara, keseimbangan kemajuan dan kesatuan ekonomi nasional (lihat Pasal 3 UU No. 25 Tahun 2007). Kemudian juga diatur mengenai izin. Dalam Pasal 26 UU No. 25 Tahun 2007 dikatakan:

Ayat (1) : Pelayanan terpadu satu pintu bertujuan membantu penanam modal dalam memperoleh kemudahan pelayanan, fasilitas fiscal, dan informasi mengenai penanaman modal. 
Ayat (2) Pelayanan terpadu satu pintu dilakukan oleh lembaga atau instansi yang berwenang di bidang penanaman modal yang mendapat pendelegasian atau pelimpahan wewenang dari lembaga atau instansi yang memiliki kewenangan perizinan dan nonperizinan di tingkat pusat atau lembaga atau instansi yang berwenang mengeluarkan perizinan dan non perizinan di propinsi atau kabupaten/kota.

Ayat (3) Ketentuan mengenai tata cara dan pelaksanaan pelayanan terpadu satu pintu sebagaimana dimaksud pada ayat (2) diatur dengan Peraturan Presiden.

“Perusahaan penanaman modal yang akan melakukan kegiatan usaha wajib memperoleh izin sesuai dengan peraturan perundang-undangan dari instansi yang memiliki kewenangan kecuali ditentukan lain dalam undang-undang".

Pasal 13 ayat (5)-nya mengatakan:

“Izin sebagaimana dimaksud pada ayat (4) dapat diperoleh melalui pelayanan terpadu".

Memperhatikan pasal tersebut jelas izin masih sektoral, sedangkan bentuk pelayanannya adalah terpadu. Padahal berdasarkan ketentuan yang sekarang berlaku, adalah pelayanan satu atap.

Secara struktur hukum, dalam UU Penanaman Modal terdapat pula asas yang menjungjung kepastian hukum. Hal tersebut dapat dilihat Pasal 3 ayat (1) yang mengatakan:

“Penanaman Modal diselenggarakan berdasarkan pada asas:

Copyright @ 2015 , LITIGASI, p-ISSN: 0853-7100; e-ISSN: 2442-2274 
Available online at: http://ejournal.unpas.ac.id/index.php/litigasi

Litigasi, Vol. 16(2), 2015, 2906-2938

DOI: http://dx.doi.org/10.23969/litigasi.v16i2.38

a. Kepastian hukum;

b. Keterbukaan;

c. Akuntabilitas; dan

d. Perlakuan yang sama dan tidak membedakan asal negara".

Dengan dimasukannya kepastian hukum dalam batang tubuh UU Penanaman Modal, berarti kepastian hukum tidak saja sebagai suatu asas hukum, tetapi sudah menjadi kaidah hukum. UU tersebut disusun dengan memperhatikan prinsip umum yang meliputi Kepastian hukum, Keterbukaan, Akuntabilitas, dan Perlakuan yang sama dan tidak membedakan asal negara (national treatment dan non-diskriminasi), perlu pula didukung dengan kebijakan fasilitasi dengan undangundang perpajakan, ketenagakerjaan, dan urusan pemerintahan di bidang penanaman modal (Keterangan Pemerintah dalam penyampaian RUU Penanaman Modal kepada Dewan Perwakilan Rakyat, bulan Nopember tahun 2005: 3-4).

Memperhatikan substansi rumusan dalam UU Penanaman Modal memiliki semangat untuk menciptakan efektivitas dan efisiensi, namun demikian masih terdapat kewenangan yang masih diberikan kepada instansi sektoral. Hal ini apabila koordinasi seperti sekarang, maka walaupun sudah dibentuk peraturan penanaman modal yang baru, masih mencerminkan semangat yang telah berlangsung selama ini. Terlebih masalah yang baru saja muncul tentang pengupahan. Pemerintah dengan mengeluarkan PP 78 Tahun 2015 apabila melihat penjelasan umum undang-undang tersebut maksudnya adalah supaya

Copyright @ C 2015, LITIGASI, p-ISSN: 0853-7100; e-ISSN: 2442-2274 
terdapat kesamaan pengertian tentang sistem pengupahan, dengan demikian dapat dikatakan ingin terwujudnya kepastian dalam sistem pengupahan baik bagi pengusaha maupun tenaga kerja. Yang paling penting menurut penulis adalah terciptanya keseimbangan antara kepentingan tenaga kerja dan pengusaha. Masalah tersebut kalau didekati dengan pendekatan ekonomi terhadap hukum, maka dapat dikemukan suatu konsep yaitu Pareto Efficiency : suatu kebijakan yang diandaikan terdapat tidak satu pihak yang merasa diuntungkan dan tidak ada pihak lain yang merasa dirugikan. Jika sebaliknya jika sebuah kebijakan atau perubahan hukum membuat setidak-tidaknya satu pihak merasa diuntungkan dan tidak ada satupun pihak yang merasa dirugikan inilah yang disebut dengan istilah Superioritas Pareto atau Pareto Optimally. Dua konsep tersebut untuk melihat pendekatan ekonomi terhadap hukum sebagaimana dikemukakan oleh Vilfredo Federico Damaso Pareto (1848-1923) (Jeffrey L. Harison, 1995: 32-33 dalam Ahmad Ridwan Tantowi, 132).

Konsep ini dapat menyelesaikan persolan hubungan tenaga kerja/buruh dan pengusaha sebagaimana persoalan keluarnya PP No. 78 Tahun 2015 tentang Pengupahan.

Melihat pentingnya peran investasi dalam memberikan sumbangan kepada pertumbuhan ekonomi, maka untuk meningkatkan daya tarik, perlu dilakukan penyederhanaan sistem hukum investasi, khususnya dalam implementasi otonomi daerah, yaitu harus diciptakan suatu model yang mengandung penyederhanaan sebagai berikut:

Copyright (C) 2015, LITIGASI, p-ISSN: 0853-7100; e-ISSN: 2442-2274 
Available online at: http://ejournal.unpas.ac.id/index.php/litigasi

Litigasi, Vol. 16(2), 2015, 2906-2938

DOI: http://dx.doi.org/10.23969/litigasi.v16i2.38

1. Penyederhanaan kewenangan kelembagaan termasuk kewenangan pemberian izin investasi;

2. Bentuk hukum investasi sebaiknya mereduksi berbagai aturan hukum yang berkaitan dengan kegiatan investasi, seperti menentukan besarnya nilai fasilitas pajak, biaya pengurusan izin, sehingga menjadi jelas dan transparan, kemudian persoalan tenaga kerja perlu adanya pengaturan dengan memperhatikan konsep Pareto atau optimally efficiency;

3. Perlu dipikirkan dalam implementasi perizinan dengan memperhatikan kualifikasi izin terintegrasi atau berantai.

Dengan berbagai penyederhanaan tersebut, maka dalam bentuk pelayanan perlu juga diselaraskan dengan bentuk penyederhanaan izin yang sifatnya masih sektoral. Apabila berhasil, maka dalam bidang investasi, khususnya perizinan telah melakukan perubahan model paradigma sebagaimana dikemukakan oleh Thomas Khun.

Copyright $\odot$ 2015, LITIGASI, p-ISSN: 0853-7100; e-ISSN: 2442-2274 
Available online at: http://ejournal.unpas.ac.id/index.php/litigasi

Litigasi, Vol. 16(2), 2015, 2906-2938

DOI: http://dx.doi.org/10.23969/litigasi.v16i2.38

\section{SIMPULAN DAN SARAN}

\section{A. SIMPULAN}

1. Jaminan kepastian hukum berinvestasi telah menjadi politik hukum Indonesia sebagaimana tertuang di dalam Undang-Undang Penanaman Modal No. 25 Tahun 2007. Wujudnya dengan adanya kaidah perlindungan dari tindakan nasionalisasi, pemberian kompensasi apabila terjadi tindakan nasionalisasi, perlindungan dalam proses penyelesaian sengketa melalui mekanisme musyawarah dan mufakat.

2. Konsep hukum investasi yang mendorong jaminan kepastian hukum yang terdapat dalam berbagai perundang-undangan terdapat banyak norma untuk mewujudkannya, mulai rumusan kaidah sampai pola penyelesaian sengketa.

\section{B. SARAN}

1. Untuk mendorong tingkat kepastian hukum dengan memperhatikan aspek efisiensi, maka perlu dimiliki database mengenai geografi information system dan demografi information system.

2. Perlu adanya harmonisasi aturan pusat dan daerah tentang implementasi kebijakan investasi, melalui harmonisasi, sinkronisasi aturan hukum yang terkait investasi, dan penyederhanaan jenis izin investasi yang mencakup aspek birokrasinya juga aturan hukumnya.

Copyright (C) 2015, LITIGASI, p-ISSN: 0853-7100; e-ISSN: 2442-2274 


\section{DAFTAR PUSTAKA}

\section{BUKU}

Aminuddin Ilmar, 2004, Hukum Penanaman Modal Di Indonesia, Jakarta, Prenada Media.

Ateng Syafrudin, 2006, Kapita Selekta ; Hakikat Otonomi \& Desentralisasi Dalam Pembangunan Daerah, Yogyakarta, Citra Media Hukum.

(Penerjemah), 2006, FAM Stroink, Pemahaman Tentang Dekosentrasi, Bandung, Refika Aditama.

A. Sonny Keraf, 1998, Etika Bisnis; Tuntutan Dan Relevansinya, Yogyakarta, Pustaka Filsafat.

A.V. Dicey, 1952, Introduction to the Study of the Law of The Constitution, Ninth Edition, Mac Millan And Co. Limited, London.

Bagir Manan (editor), 1996, Kedaulatan Rakyat, Hak Asasi Manusia, dan Negara Hukum, Jakarta, Gaya Media Pratama.

Bagir Manan, 1999, Lembaga Kepresidenan, Yogyakarta, Pusat Studi Hukum Universitas Indonesia, Gama Media.

2004, Menyongsong Fajar Otonomi Daerah, Yogyakarta, Pusat Studi Hukum Fakultas Hukum UII. , 2004,Teori dan Politik Konstitusi, Yogyakarta, FH UII Press.

Bagir Manan dan Kunta Magnar, 1993, Beberapa Masalah Hukum Tata Negara Indonesia, Bandung, Alumni.

Bagir Manan, Pembinaan Hukum Nasional, terpetik dalam Mieke Komar, et.al (editor), Mochtar Kusumaatmadja: Pendidik \& Negarawan ; Kumpulan Karya Tulis Menghormati 70 Tahun Prof. Dr. Mochtar Kusumaatmadja, SH.,LL.M.

Badudu-Zein, 1994, Kamus Umum Bahasa Indonesia, Jakarta, Sinar Harapan.

Burton, J., Steven., 1995, An Introduction To Law And Legal Reasoning, Aspen Publisher, Inc.

Clasen, F. Thomas, 1994, Foreign Trade and Investment, Wisconsin, Foley \& Lardner Milwaukee.

Copyright @ 2015 , LITIGASI, p-ISSN: 0853-7100; e-ISSN: 2442-2274 
Huala Adolf, 2005, Hukum Perdagangan Internasional, Jakarta, Rajawali Press.

Joko Widodo, 2004, Good Governance, Jakarta, Insan Cendekia.

Lawrence M. Friedman, 1975,The Legal System; A Social Science Perspective, New York, Russel Sage Foundation.

Mardiasmo, 2002, Otonomi dan Manajemen Keuangan Daerah, Yogyakarta, Andi.

Prajudi Atmosudirdjo, 1998, Hukum Administrasi Negara, Ghalia Indonesia.

Romli Atmasasmita, 2006, Pengantar Hukum Kejahatan Bisnis, Jakarta, Kencana.

Spelt N.M. dan ten Berge, J.B.J.M. disunting oleh Philipus M. Hadjon, 1993, Pengantar Hukum Perizinan, Surabaya, Yuridika.

Soerjono Soekanto, 1983, Penegakan Hukum, Bandung, Binacipta.

Talijiduhu Ndraha, 2000, IImu Pemerintahan, Jakarta, Materi Kuliah Kerjasama UNPAD-IIP.

Wirjono Prodjodikoro, 1981, Asas-asas IImu Negara dan Politik, Jakarta-Bandung, Eresco.

\section{JURNAL}

Sjahran Basah, 1996, Sistem Perizinan Lingkungan Sebagai Instrumen Pengendalian Lingkungan, Bandung, Media Komunikasi, FH Unpas, Edisi 23.

\section{MAJALAH}

Syahriel Nochtar, 2001, Pepesan Kosong Dana Otda, Infobank, edisi April.

\section{TESIS}

Ahmad Ridwan Tantowi, Tesis "Politik Hukum Pengelolaan Usaha Kepelabuhanan Nasional Dalam Rangka Menyongsong Masyarakat Ekonomi Asean (MEA) Dihubungkan Dengan UU No. 17 Tahun 2008 tentang Pelayaran, MIH Pascasarjana Unpas. 
Available online at: http://ejournal.unpas.ac.id/index.php/litigasi

Litigasi, Vol. 16(2), 2015, 2906-2938

DOI: http://dx.doi.org/10.23969/litigasi.v16i2.38

\section{MAKALAH}

Bagir Manan, 2002, Penerapan penegakan Hukum Lingkungan Di Indonesia, Makalah pada Simnar, Bandung, FH Unpad.

Mochtar Kusumaatmadja, 1995, Investasi di Indonesia dalam Kaitannya dengan Pelaksanaan Perjanjian Putaran Uruguay, makalah disampaikan dalam pelatihan Implementasi GATT, Unpad.

\section{MEDIA MASA}

Juwono Sudarsono, 2004,Tiga L Pemikat Investasi di Indonesia, Kompas Edisi Rabu 9 Juni.

Robert Endi Jaweng, 2006, Ihwal Perda Bermasalah, Kompas, Jumat 24 Maret. 